\title{
NO-ЕРГИЧЕСКАЯ СИСТЕМА - МИШЕНЬ ДЛЯ ПОВЫШЕНИЯ ЭФФЕКТИВНОСТИ ПРОТИВОДИАБЕТИЧЕСКИХ ЛЕКАРСТВЕННЫХ СРЕДСТВ (НА ПРИМЕРЕ ЛИРАГЛУТИДА)
}

\author{
Д.В. Куркин', Д.А. Бакулин², Е.Е. Абросимова², М.А. Дубровина², \\ И.Н. Тюренков ${ }^{2}$ \\ ${ }^{1}$ НЦИЛС, ВолгГМУ, 400131, Россия, Волгоград, площадь Павших Борцов, д. 1. \\ ${ }^{2}$ Кафедра фармакологии и фармации Института НМФО, ВолгГМУ Минздрава России, \\ 400131, Россия, Волгоград, площадь Павших Борцов, д. 1.
}

DOI: 10.19163/MedChemRussia2021-2021-86

E-mail: Strannik986@mail.ru

Нарушения в функционировании NO-ергической системы сопровождает развитие многих заболеваний, в том числе сахарного диабета и его осложнений. Активация эндотелиальной NO-синтазы может уменьшать сосудистые осложнения сахарного диабета. Подавление активности индуцибельной NO-синтазы является перспективным направлением нейропротекции [1-3].

Значительный вклад NO-ергической системы в патогенез СД2 и данные экспериментальных исследований о влиянии модуляторов её активности на эффективность гипогликемической терапии обуславливают перспективность создания новых противодиабетических средств в виде комбинации известного лекарства с модификатором синтеза NO. На модели СД2 исследована гипогликемическая активностьагониста ГПП-1 в сочетании с блокаторами или активаторами различных изоформ NO-синтаз. В результате исследования было установлено, что однократное и курсовое введение аминогуанидина (блокатор iNOS) как изолированно, так и в комбинации с лираглутидом значительно снижает концентрацию глюкозы в крови при измерении натощак и предупреждает её увеличение в пероральном тесте толерантности к глюкозной нагрузке. Добезилат кальция (активатор eNOS) и L-аргинин (субстрат для синтеза NO) совместно с лираглутидом значимо увеличивало гипогликемическое действие последнего. Таким образом модификация активности определенных NO-синтаз может влиять на противодиабетическое действие лираглутида. Эти результаты могут лечь в основу новой стратегии лечения СД и его осложнений, целенаправленного пути разработки новых препаратов или их комбинаций.

\section{Литература}

[1] Sansbury B.E., Hill B.G. Regulation of obesity and insulin resistance by nitric oxide. Free RadicBiol Med. 2014, 73, 383-99.

[2] Sena C.M., Pereira A.M., Seiça R. Endothelial dysfunction - a major mediator of diabetic vascular disease. BiochimBiophysActa. 2013;1832(12):2216-31.

[3] Куркин Д.В., Волотова Е.В., Бакулин Д.А. и др. Система инкретинов как перспективная фармакологическая мишень для сахароснижающей терапии // Фарматека. 2016. № 5. - C. 45-50. 